\title{
TERAMPIL
} Jurnal Pendidikan dan Pembelajaran Dasar

\section{PENGEMBANGAN LEMBAR KERJA SISWA (LKS) IPA BERBASIS ICT SEBAGAI MEDIA PEMBELAJARAN \\ QOMARIO}

Email: qomario@stkipalitb.ac.id PUTRY AGUNG

Email: qomario@stkipalitb.ac.id

STKIP Al Islam Tunas Bangsa Bandar Lampung

Volume 5 Nomor 2, Desember 2018

\begin{abstract}
Abstrak
Kompetensi guru sangat diperlukan dalam pencapaian tujuan pendidikan, namun pada kenyataannya kemampuan calon guru belum sepenuhnya mengembangkan kompetensinya dikarenakan guru belum mengenal Teknologi Infromasi dan Komunikasi (TIK). Oleh karena itu, perlu dilakukan pengembangan LKS berbasis ICT sebagai modal awal calon guru profesional. Penelitian ini dilatarbelakangi banyaknya calon guru yang kurang mampu menggunakan ICT sebagai bagian dari sumber belajar. Tujuan Penelitian ini untuk; (1) Mendeskripsikan kondisi dan potensi untuk dikembangkannya pengembangan LKS berbasis ICT di STKIP Al ITB Bandar Lampung; (2) Mengembangkan LKS berbasis ICT di STKIP Al ITB Bandar Lampung; (3) Menghasilkan prototype pengembangan LKS berbasis ICT di STKIP Al ITB Bandar Lampung. Penelitian ini menggunakan Metode R\&D dengan langkah-langkah; (1) Analysis (analisa), (2) Design (desain), (3) Development (pengembangan), (4) Implementation (implementasi/eksekusi), (5) Evaluation (evaluasi/ umpan balik). Alat pengumpulan data yang digunakan yaitu; (1) angket, (2) diskusi, (3) wawancara. Alat analisis data yang dilakukan yaitu analisis deskriptif kuantitatif dan analisis deskriptif kualitatif. Penelitian ini menghasilkan produk LKS berbasis ICT. Hasil Kemenarikan prototipe sebesar 88,43\% dengan kategori sangat baik digunakan. Hasil Kemudahan untuk mahasiswa sebesar 87,15\% dengan kategori sangat baik digunakan. Hasil penilaian angket menunjukkan bahwa mahasiswa menyukai pembelajaran dengan prototipe karena menambah ilmu pengetahuan dan panduan prototipe mudah digunakan.
\end{abstract}

Kata kunci: LKS, Berbasis ICT, Guru Profesional 


\section{A. PENDAHULUAN}

Sesuai dengan undang-undang No. 14 tahun 2005 tentang Guru \& Dosen, guru mempunyai kedudukan sebagai tenaga profesional pada jenjang pendidikan dasar, pendidikan menengah, dan pendidikan anak usia dini pada jalur pendidikan formal yang diangkat sesuai dengan peraturan perundang-undangan. Sebagai pendidik profesional guru memiliki tugas utama mendidik, mengajar, membimbing, mengarahkan, melatih, menilai, dan melaksanakan evaluasi peserta didik pada pendidikan anak usia dini jalur pendidikan formal, pendidikan dasar, dan pendidikan menengah. Tugas utama tersebut didukung dengan adanya Teknologi Informasi dan Komunikasi (TIK).

Teknologi Informasi dan Komunikasi atau Information Communication and Technology di era industry 4.0 sudah menjadi kebutuhan wajib untuk mendukung segala sesuatu yang kita lakukan, terutama di dunia pendidikan. Pendidikan berbasis TIK merupakan sarana yang sangat penting baik untuk manajemen, admistrasi, tenaga kependidikan, pendidik maupun peserta didik dalam meningkatkan mutu pendidikan.

Berdasarkan paparan di atas, salah satu kompetensi guru yang menekankan pada aspek penggunaan media berbasis TIK atau Information and Communication Technology (ICT) tertuang dalam kompetensi guru pada aspek profesional. Seorang guru yang profesional seharusnya mampu mengajarkan peserta didik mengolah dan memanfaatkan tekhnologi informasi dengan lingkungan yang dimiliki peserta didik. Hal ini akan membantu mempermudah peserta didik untuk memahami siapa dirinya, dan peserta didik akan menjadi dirinya sendiri, serta dapat menyesuaikan dengan tuntutan lingkungan.

Berdasarkan pernyataan di atas mahasiswa STKIP Al Islam Tunas Bangsa sebagai calon guru sudah sewajarnya harus mempersiapkan diri untuk memiliki kemampuan tersebut. Kemampuan penggunaan media berbasis teknologi informasi dan komunikasi wajib dimiliki calon guru, jika mereka tidak mau ketinggalan dan menjadi "asing" di masyarakat yang telah dikelilingi dunia teknologi informasi dan komunikasi. Dengan dimilikinya kemampuan tersebut pada diri calon guru, akan memudahkan mereka untuk merealisasikan slogan "lifelong education".

Selain dari kemampuan penggunaan berbasis teknologi informasi dan komunikasi seorang calon guru harus mampu mengembangkan bahan ajar yang mampu menjadikan peserta didik untuk lebih berpikir kritis. LKS adalah salah satu bahan ajar yang mempunyai peran penting dalam pencapaiaan keberhasilan proses belajar mengajar seperti hanya pembelajaran IPA. Lembar Kerja Siswa (LKS) dapat diartikan sebuah materi pembelajaran yang telah diolah dan dikemas semaksimal mungkin, sehingga peserta didik mudah untuk memahami materinya sekalipun belajar mandiri.

Integrasi Lembar Kerja Siswa (LKS) berbasis teknologi informasi dan komunikasi akan menjadi modal utama sebagai calon guru profesional. Sejalan dengan pendapat 
Rusman guru dalam era teknologi informasi dan komunikasi sekarang ini tidak hanya sekedar mengajar (mentransfer pengetahuan) akan tetapi harus menjadi manajer belajar. Artinya, setiap pendidik seharusnya mampu membuat peserta didik menjadi kreatif, aktif, termotivasi, mampu menggunakan multimedia, multumetode, dan multi sumber agar tujuan pembelajaran yang diharapkan tercapai secara maksimal. (Rusman, 2011:19)

Berdasarkan uraian yang telah dikemukakan di atas, maka perlu dikembangkan lembar kerja siswa berbasis ICT, yang dapat mempersiapkan calon guru untuk menguasai keahliannya sebagai calon guru profesional.

\section{B. KAJIAN TEORITIK \\ 1. Definisi Bahan Ajar}

Bahan ajar merupakan bagian penting dalam kegiatan belajar mengajar. Hal ini sejalan dengan pendapat Mulyasa yang mengungkapkan bahwa bahan ajar termasuk bagian dari sumber ajar yang dapat diartikan sesuatu yang mengandung pesan pembelajaran, dan dapat dimanfaatkan dalam proses belajar mengajar. (Mulyasa, 2006: 96)

Dick, Carey, dan Carey menambahkan bahwa instructional material contain the conten either written, mediated, or facilitated by an instructor that a student as use to achieve the objective also include information thet the learners will use to guide the progress. (Dick, Carey, dan Carey, 2009: 230) Berdasarkan ungkapan Dick, Carey, dan Carey dapat diketahui bahwa bahan ajar segala sesuatu bahan yang dapat diolah menjadi pengetahuan atau materi pelajaran, bahan ajar sendiri ada yang berbentuk cetak dan yang non cetak. Bahan ajar cetak dapat berupa, handout, buku, modul, brosur, dan lembar kerja siswa. Sedangkan bahan ajar noncetak meliputi, bahan ajar audio seperti, kaset, radio, piringan hitam, dan compact disc audio. Bahan ajar audio visual seperti, CAI (Computer Assisted Instruction), dan bahan ajar berbasis web (web based learning materials) (Ika Lestari, 2013: 5).

Lebih lanjut ungkapan Mulyasa bahwa ada beberapa macam bentuk bahan ajar seperti bahan ajar cetak (hand out, buku, modul, LKS, brosur, dan leaflet), audio (radio, kaset, cd audio), visual (foto atau gambar), audio visual (video/ film atau VCD) dan multimedia (CD interaktif, computer based, dan internet). (Mulyasa, 2006: 96)

Berdasarkan uraian di atas dapat disimpulkan bahwa bahan ajar merupakan salah satu sumber belajar yang salah satunya dalam bentuk Lembar Kerja Siswa (LKS). Bahan ajar sangat memengaruhi hasil belajar, denga bahan ajar dapat belajar secara mandiri.

2. Lembar Kerja Siswa (LKS)

Lembar Kerja Siswa adalah sumber belajar penunjang yang dapat meningkatkan pemahaman siswa mengenai materi kimia yang harus mereka kuasai. (Senam, 2008) LKS termasuk dalam media belajar cetak yang merupakan alat bantu untuk menyampaikan informasi dari pendidik kepada peserta didik dalam proses belajar mengajar. LKS mempunyai fungsi untuk mempermudah penyampaian 
informasi yang dikehendaki. Dan dapat mengefektifkan waktu.

3. Media Pembelajaran Berbasis ICT

Media pembelajaran berbasis ICT merupakan alat yang digunakan dalam proses belajar mengajar dengan mengacu pada pemanfaatan teknologi informasi. Dimana dalam proses belajar mengajar ini baik pendidik dan peserta didik tidak harus saling bertemu secara fisik tetapi juga bisa memanfaatkan teknologi.

Dewasa ini, Fenomena pemanfaatan ICT terutama dikalangan mahasiswa sangatlah penting dan tidak bisa dilepaskan keterkaitannya. Perkembangan ICT mendulang pesat sesuai dengan kemajuan zaman. Setiap hal yang dilakukan berkaitan dengan teknologi terutama dunia pendidikaan. Karena teknologi informasi menyimpan informasi tentang banyak hal yang tidak terbatas ruang dan waktu.

\section{METODE PENELITIAN}

1. Jenis dan Prosedur Penelitian

Penelitian ini menggunakan metode Research And Development. Desain penelitian Research And Development menurut Reiser dan Mollenda yang dikenal dengan ADDIE memiliki beberapa langkah. Adapun langkah-langkah pengembangannya adalah sebagai berikut:

a. Analysis (analisa), yaitu melakukan needs assessment (analisis kebutuhan), mengidentifikasi masalah (kebutuhan), dan melakukan analisis tugas (task analysis). b. Design (desain/perancangan), yang kita lakukan dalam tahap desain ini mengadopsi dari ASSURE yang dikembangkan peneliti untuk disesuaikan dengan potensi \& kondisi penelitian. Berikut tahapantahapan yang dilakukan; (1) Analyze learners yaitu menganalisis pembelajar pada tahap ini sama dengan tahap awal pengembangan, (2) State Objectives yaitu menetapkan tujuan pembelajaran, (3) Select methods, media, materials yaitu memilih metode, media dan bahan, (4) Utilize materials yaitu memanfaatkan bahan ajar. langkah kelima (Require learners participation) dan keenam Evaluate and revise yaitu evaluasi dan revisi proses pembelajaran tidak dilakukan, karena langkah kelima dan keenam sudah terdapat pada proses pengembangan model ADDIE.

c. Development (pengembangan), pengembangan adalah proses validasi atau kegiatan untuk menguji kelayakan oleh para pakar.

d. Implementation (implementasi/ eksekusi), implementasi adalah kegiatan untuk menilai produk LKS berbasis ICT yang sudah dibuat.

e. Evaluation (evaluasi/ umpan balik), yaitu proses untuk melihat apakah LKS berbasis ICT yang dikembangkan berhasil atau tidak, seperti tujuan awal pengembangan. Evaluasi ini pada dasarnya dapat dilakukan pada setiap tahap analysis, design, development, 
dan implementasi. Evaluasi yang terjadi pada setiap empat tahap di atas itu dinamakan evaluasi formatif, karena tujuannya untuk kebutuhan revisi.

Prosedur pengembangan model pelatihan literasi media dan informasi dalam penelitian ini penulis gambarkan pada bagan berikut :

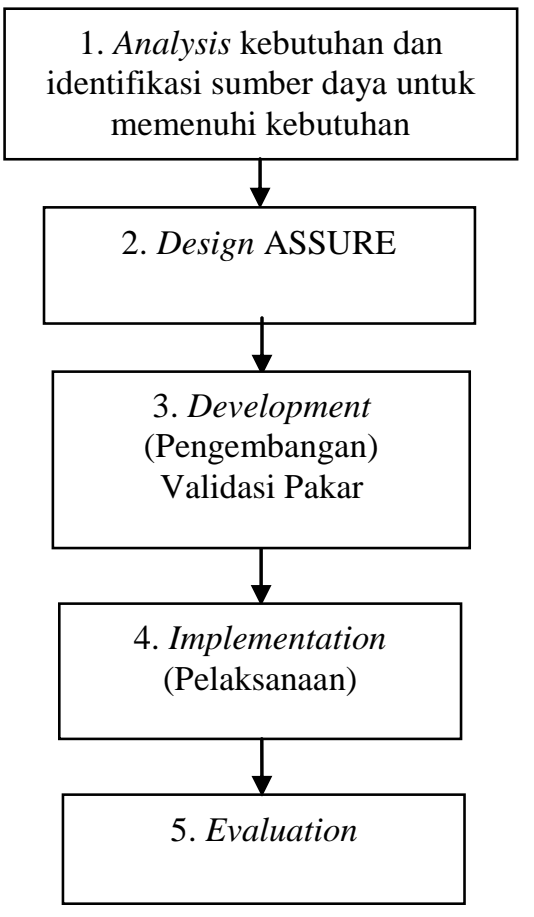

Gambar 1 Prosedur Penelitian

\section{Alat Pengumpulan Data}

Penelitian ini menggunakan alat pengumpulan data seperti::

a. Pada tahap penelitian analisis kebutuhan digunakan teknik wawancara, untuk menggali data berkenaan dengan kemampuan membuat LKS dan menggunakan ICT.

b. Pada tahap pengembangan digunakan teknik diskusi dan analisis saran serta masukan dari tim ahli (expert judgement). c. Pada tahap pelaksanaan (implementtation) digunakan angket dan catatan kejadian.

3. Teknik Analisis Data

Teknik analisis data yang digunakan dalam penelitian yaitu dengan memberikan respon penilaian dengan empat instrument jawaban. Kriteria skala penilaiaan terdapat pada tabel berikut:

Tabel 1

Kriteria Skala Penilaian

\begin{tabular}{ccc}
\hline Kategori & $\begin{array}{c}\text { Bobot } \\
\text { Nilai }\end{array}$ & $\begin{array}{c}\text { Persentase } \\
(\boldsymbol{\%})\end{array}$ \\
\hline Sangat Baik & 4 & $76-100$ \\
Baik & 3 & $51-75$ \\
Tidak Baik & 2 & $26-50$ \\
Sangat Tidak & 1 & $0-25$ \\
Baik & & \\
\hline
\end{tabular}

Pada Tabel 1 menunjukkan empat kriteria skala penilaian. Skala penilaian diperoleh dari hasil jawaban lembar angket yang diberikan mahasiswa. Langkah selanjutnya total jawaban ditentukan dengan mengkalikan jumlah responden dengan bobot nilainya, dan menujukkan semua hasilnya. Setelah melakukan penjumlahan jawaban responden, langkah selanjutnya adalah menentukan prosentase penilaian mahasiswa dengan menggunakan rumus:

$H R=\frac{\sum \text { jawaban responden }}{\sum \text { nilai tertinggi responden }} \times 100 \%$

Keterangan :

HR $=$ Hasil Responden

$\sum$ Jawaban responden $=$ Jumlah total jawaban responden

$\sum$ Nilai tertinggi responden $=$ Jumlah total nilai tertinggi responden. (Widoyoko, 2012:110) 


\section{HASIL PENELITIAN DAN PEMBAHASAN \\ 1. Analisis Kebutuhan}

Studi lapangan yang dilakukan terhadap 35 mahasiswa melalui instrumen angket untuk mengetahui kebutuhan mahasiswa terhadap pengembangan media berbasis ICT di dalam hal ini spesifikasi yang digunakan Lembar Kerja Siswa IPA, terdapat pada Tabel 2 berikut:

Tabel 2

Hasil Analisis Kebutuhan

\begin{tabular}{|c|c|c|c|}
\hline \multirow{2}{*}{$\begin{array}{l}\mathrm{N} \\
\mathrm{o}\end{array}$} & \multirow{2}{*}{ Pertanyaan } & \multicolumn{2}{|c|}{ Jawaban \% } \\
\hline & & $Y$ & $\mathbf{T}$ \\
\hline $\begin{array}{l}1 \\
.\end{array}$ & $\begin{array}{l}\text { Apakah Anda } \\
\text { mengetahui buku } \\
\text { lembar kerja siswa? } \\
\text { Apakah bentuk dari }\end{array}$ & $\begin{array}{c}100 \\
\%\end{array}$ & $0 \%$ \\
\hline 2 & $\begin{array}{l}\text { lembar kerja siswa } \\
\text { yang anda ketahui } \\
\text { berupa media cetak? }\end{array}$ & $\begin{array}{c}100 \\
\%\end{array}$ & $0 \%$ \\
\hline $\begin{array}{l}3 \\
.\end{array}$ & $\begin{array}{l}\text { Apakah Anda pernah } \\
\text { memanfaatkan LKS } \\
\text { berupa media cetak? }\end{array}$ & $30 \%$ & $\begin{array}{l}70 \\
\%\end{array}$ \\
\hline 4 & $\begin{array}{l}\text { Apakah Anda sering } \\
\text { memanfaatkan } \\
\text { Teknologi dan } \\
\text { informasi sebagai } \\
\text { sumber belajar? }\end{array}$ & $70 \%$ & $\begin{array}{l}30 \\
\%\end{array}$ \\
\hline 5 & $\begin{array}{l}\text { Apakah Anda pernah } \\
\text { membuat LKS } \\
\text { berbasis ICT? }\end{array}$ & $0 \%$ & $\begin{array}{c}100 \\
\%\end{array}$ \\
\hline 6 & $\begin{array}{l}\text { Penulis akan } \\
\text { mengembangkan } \\
\text { LKS IPA berbasis } \\
\text { ICT, apakah anda } \\
\text { membutuhkan? }\end{array}$ & $90 \%$ & $\begin{array}{l}10 \\
\%\end{array}$ \\
\hline
\end{tabular}

Berdasarkan tabel di atas diketahui mahasiswa mengenal lembar kerja siswa berbentuk media cetak, tetapi belum sepenuhnya dimanfaatkan. Tingkat antusias di dalam pemanfaatan teknologi dan informasi sebesar $80 \%$ artinya mahasiswa sudah sering sekali memanfaatkan TIK sebagai sumber belajar. Jawaban pertanyaan yang diberikan pada nomor 5 dan 6 menunjukkan adanya keinginan mahasiswa untuk diberikan pengembangan lembar kerja siswa IPA berbasis ICT.

2. Hasil Prototipe LKS IPA Berbasis ICT

Sebelum pelaksanaan pengembangan prototype dilakukan desain pembelajaran berikut prosesnya:

a. Analyze Learner, menganalisis target pembelajar yang akan dilakukan pelaksanaan pengembangan prototipe dalam hal ini semester 4 dan 6 program studi pendidikan guru sekolah dasar.

b. State objectives, proses merumuskan tujuan pembelajaran yang tertera pada kontrak kuliah

c. Select instructional methods, media and material, pada tahap ini memilih metode pendekatan, media yang digunakan dan kebutuhan lain yang mendukung proses pengembangan

d. Tahap Utilize media and material, Require learner participation, dan Evaluate and revise sudah masuk dalam tahap pengembangan.

Hasil Pengembangan LKS IPA berbasis ICT meliputi pengembangan isi LKS dan pengembangan draft LKS. Pada tahap pengembangan isi LKS, yang dikembangkan adalah materi-materi, soal-soal dan video pembelajaran IPA yang berkaitan dengan materi yang ingin dimasukkan ke dalam media yang dibuat. Pada tahap pengembangan draft LKS yang dilakukan oleh 
peneliti adalah mengembangkan tampilan berupa element, clipart dan effect. Program utama yang digunakan peneliti untuk membuat LKS IPA berbasis ICT adalah Kvisoft Flipbook Maker 3.

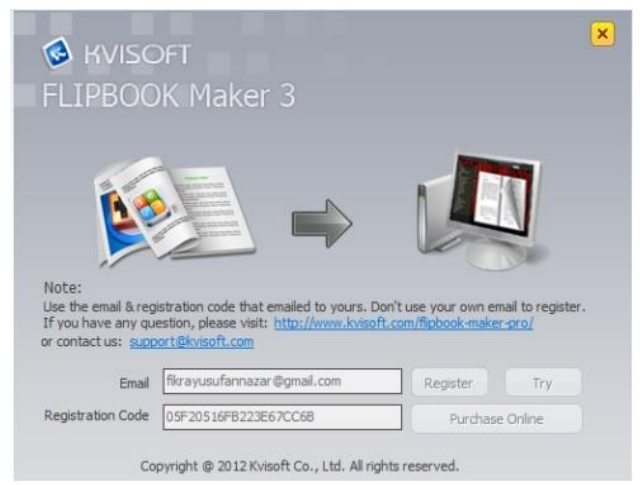

Gambar 2 Kvisoft Flipbook Maker 3

Peneliti menggunakan produk Kvisoft Flipbook Maker 3 tersebut untuk memudahkan mahasiswa di dalam mebuat sebuah produk LKS IPA berbasis ICT. Materi ajar serta animasi pembelajaran peneliti masukkan ke dalam media yang akan dibuat. Setelah proses meng-input materi selesai, peneliti kemudian mem-publish progam kedalam format exe untuk dapat dilihat hasilnya. Selanjutnya aplikasi yang telah dibuat dapat dikatakan sebagai produk akhir. Tampilan LKS berbasis ICT dapat dilihat pada gambar 3 berikut:

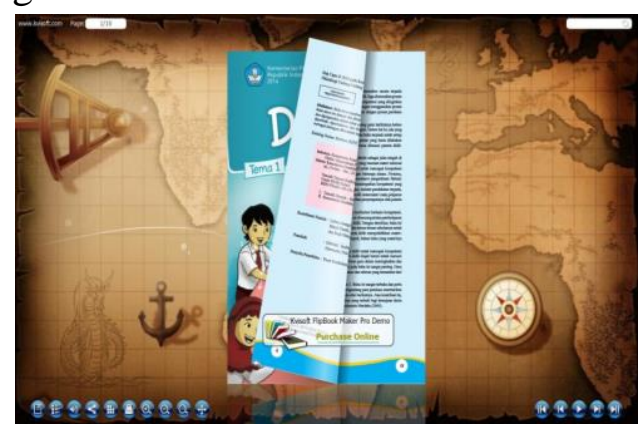

Gambar 3 Hasil Akhir LKS Berbasis ICT

\section{Hasil Pelaksanaan Pengembangan LKS IPA berbasis ICT}

Prototipe diberikan kepada mahasiswa program studi pendidikan guru sekolah dasar semester 4 dan 6 mempunyai jumlah mahasiswa sebanyak 36 mahasiswa. langkah penelitian ini bertujuan untuk mendapatkan tanggapan mahasiswa terhadap prototipe yang sudah dikembangkan. Hasil tanggapan mahasiswa dilakukan 1 kali pertemuan di dalam kelas pada mata kuliah produksi dan pemanfaatan penggunaan media serta media berbasis ICT. Mahasiswa dianjurkan untuk memilih salah satu dari empat skala penilaian yang telah disebutkan di table. 2 pada lembar angket yang berisi 5 point pertanyaan tentang kemenarikan dan kemudahan prototipe yang telah dikembangkan pada saat mahasiswa sudah memperoleh pengetahuan dan pembelajaran menggunakan Kvisoft Flipbook Maker 3. Setelah semua mahasiswa mengisi lembar angket, kemudian angket tersebut dihitung dan dianalisis. Adapun deskripsi hasil analisis angket respon mahasiswa, akan ditunjukkan pada Tabel 3 berikut:

Tabel 3

Hasil Angket Mahasiswa

\begin{tabular}{|c|c|c|c|c|}
\hline $\begin{array}{c}\text { Kriteria } \\
\text { Penilaian }\end{array}$ & $\begin{array}{c}\text { No. } \\
\text { Angket }\end{array}$ & $\begin{array}{l}\text { Jmlh } \\
\text { Nilai }\end{array}$ & $\begin{array}{l}\text { Jmlh } \\
\text { Mhs }\end{array}$ & $\begin{array}{l}\text { Hasil } \\
\text { Rating }\end{array}$ \\
\hline Kemena- & 1 & 129 & 36 & 89,58 \\
\hline rikan & 2 & 129 & 36 & 89,58 \\
\hline & 3 & 124 & 36 & 86,11 \\
\hline Jum & & 382 & 108 & 88,43 \\
\hline Kemudah- & 4 & 126 & 36 & 87,5 \\
\hline an & 5 & 125 & 36 & 86,81 \\
\hline \multicolumn{2}{|c|}{ Jumlah } & 251 & 72 & 87,15 \\
\hline
\end{tabular}

Kemenarikan prototipe pada angket mendapatkan hasil penilaian sebesar 
$88.43 \%$, dan dinyatakan dengan kategori sangat baik digunakan dengan rentang penilaian $76.00 \%-100.00 \%$. Kemudahan untuk mahasiswa mendapatkan hasil penilaian sebesar $87.15 \%$, dan dinyatakan sangat baik digunakan dengan rentang penilaian $76.00 \%$ $100.00 \%$, maka prototipe dinyatakan dalam kategori sangat baik digunakan. Hasil angket menunjukkan bahwa mahasiswa menyukai pembelajaran dengan prototipe karena menambah ilmu pengetahuan dan panduan prototipe mudah digunakan.

E. KESIMPULAN

Penelitian ini menghasilkan produk LKS berbasis ICT. Hasil Kemenarikan prototipe sebesar 88,43\% dengan kategori sangat baik digunakan. Hasil Kemudahan untuk mahasiswa sebesar $87,15 \%$ dengan kategori sangat baik digunakan. Hasil angket menunjukkan bahwa mahasiswa menyukai pembelajaran dengan prototipe karena menambah ilmu pengetahuan dan panduan prototipe mudah digunakan

\section{F. DAFTAR PUSTAKA}

Departemen Pendidikan Nasional, 2005. Undang-Undang Nomor 14 Tahun 2005, Tentang Guru dan Dosen. Depdiknas. Jakarta.

Dick, W., Carey, L., dan Carey, J.O. 2009. The Systematic Design of Instruction. Pearson. New Jersey.

Lestari, Ika. 2013. Pengembangan Bahan Ajar Berbasis Kompetensi: Sesuai dengan Kurikulum Tingkat Satuan Pendidikan. Akademia. Padang.

Mulyasa, E. 2006. Kurikulum Tingkat Satuan Pendidikan. Remaja Rosdakarya. Bandung.

Rusman. 2011. Model - Model Pembelajaran Mengembangkan Profesionalisme Guru. PT Raja Gafindo Persada. Jakarta.

Senam, dkk. 2008. Efektivitas Pembelajaran Kimia untuk Siswa SMA Kelas XI denganMenggunakan LKS Kimia Berbasis Life Skill. Diakses 28 Mei 2017 dari http://jurnal.pdii.lipi.go.id/admi n/jurnal/9308280290.pdf.

Widoyoko, Eko, P. 2012. Teknik Penyusunan Instrumen Penelitian. Pustaka Belajar. Yogyakarta. 